\title{
BOA-FÉ E POSSE INJUSTA: UMA ANÁLISE ACERCA DA INDEPENDÊNCIA ENTRE OS
}

\section{VÍCIOS DA POSSE}

\section{GOOD FAITH AND UNFAIR POSSESSION: AN ANALYSIS ON THE INDEPENDENCE \\ BETWEEN THE VICES OF POSSESSION}

Marcus Dantas*

\begin{abstract}
Resumo
$\mathrm{O}$ artigo tem como objetivo contestar a idéia de que os vícios objetivos e subjetivos da posse são independentes, tendo em vista as próprias definições de vícios com as quais a doutrina costuma trabalhar. Essa contestação é feita também através do exame dos exemplos normalmente utilizados pela doutrina para a defesa da independência. Ao final, será demonstrado que, mesmo considerando a tese da independência através do exemplo padrão da aquisição a non domino, não seria possivel obter os efeitos que normalmente se espera por esse caminho. Em última instância, os vícios subjetivos dependem necessariamente da presença de um vício objetivo para que possam fazer sentido.
\end{abstract}

Palavras-chave: vícios objetivos da posse; vícios subjetivos da posse; aquisição a non domino; usucapião; saneamento dos vícios da posse.

\begin{abstract}
The article aims to challenge the idea that the objective and subjective vices of possession are independent, given the very definitions of addiction to the doctrine which usually works. This challenge is also made by examining the examples commonly used to defend the doctrine of independence. At the end, will be shown that, even considering the independence thesis through the standard example of a non domino acquisition would not be possible to obtain the effects would normally be expected in this way. Ultimately, the subjective vices are necessarily dependent on the presence of an addiction aim to enable them to make sense.
\end{abstract}

Keywords: vices objectives of possession; subjective vices of possession; acquiring a non domino; adverse possession; sanitation of the vices of possession

\section{Introdução}

O objetivo principal do artigo é examinar se a idéia de que os vícios objetivos e subjetivos da posse são independentes entre si é correta ${ }^{1}$.

\footnotetext{
* Mestre em Direito Constitucional e Teoria Geral do Estado pela PUC-Rio. Doutor em Direito Civil pela UERJ. Professor do Departamento de Direito Privado da Universidade Federal de Juiz de Fora - MG.
} 
Tradicionalmente a posse injusta é definida como a que foi obtida através de algum dos modos viciosos previstos no artigo 1200 do Código Civil $^{2}$. Já a posse de boa-fé é aquela onde o possuidor ignora os vícios ou obstáculos que impedem a aquisição da posse ${ }^{3}$.

Tem-se, de um lado, uma aquisição objetivamente viciada e, de outro, um estado de ignorância acerca dela. A primeira vista, portanto, parece natural considerar que existe uma relação de dependência entre os dois tipos de vícios, os objetivos e os subjetivos, ou seja, um não existe sem o outro. Só haverá boa-fé ou má-fé diante de uma posse injusta, eis que a injustiça é conseqüência da aquisição viciada. Se a posse é justa, simplesmente não há razão para falar de 'boa-fé' ou 'má-fé'.

Mas, ao contrário do que essa interpretação sugere, a doutrina em geral considera que os dois âmbitos de análise dos vícios da posse são independentes. Essa autonomia é descrita pela indicação de que a posse pode ser, ao mesmo tempo, "justa" e de "boa-fé", "injusta" e de "boa-fé" e vice-versa.

Se a posse injusta é aquela obtida de maneira viciada e a de boa-fé é aquela onde se ignora a existência de um vício ou obstáculo, então uma posse "justa" - obtida de modo não vicioso - e de "boa-fé", pressupõe uma diferenciação entre os conceitos de "vício" e de "obstáculo". Como não há vício, a posse é justa, mas há um obstáculo, de modo que ela pode ser de boa-fé ou de má-fé, dependendo do conhecimento ou não acerca dele.

A intenção aqui é justamente contestar essa independência entre os vícios da posse, demonstrando que o legislador não fez essa diferenciação a

\footnotetext{
1 "Nem sempre se confundem os conceitos de posse justa e posse de boa-fé. Um possuidor de boa-fé pode ter posse injusta. (...) Também é perfeitamente possivel que alguém possua de má-fé, sem que tenha obtido a posse de forma violenta, clandestina ou precária." VENOSA: 2011; p.74.

2 “Art. 1.200. É justa a posse que não for violenta, clandestina ou precária." O conceito é construído pela interpretação a contrario do artigo.

3 “Art. 1.201. É de boa-fé a posse, se o possuidor ignora o vício, ou o obstáculo que impede a aquisição da coisa.

Parágrafo único. O possuidor com justo título tem por si a presunção de boa-fé, salvo prova em contrário, ou quando a lei expressamente não admite esta presunção."
} 
sobredita diferenciação e, como conseqüência, só haverá posse de boa-fé ou de má-fé diante de uma posse injusta.

\section{A independência entre os vicios da posse e a sua critica}

É muito comum encontrar citações ao pensamento de Orlando Gomes quando se faz referência a defesa da tese da independência entre os vícios e, não raro, a seguinte passagem costuma ser utilizada:

"Não há coincidência necessária entre a posse justa e a posse de boa-fé. À primeira vista, toda posse justa deveria ser de boa-fé e toda posse de boa-fé deveria ser justa. Mas, a transmissão dos vícios de aquisição permite que um possuidor de boa-fé tenha posse injusta, se a adquire de quem a obteve pela violência, pela clandestinidade ou precariedade, ignorante da ocorrência; Também é possivel que alguém possua de má-fé, embora não tenha posse violenta, clandestina ou precária."4 (2010; p.50)

Em primeiro lugar o autor escreve que, a princípio, 'toda posse justa deveria ser de boa-fé e toda posse de boa-fé deveria ser justa'. O trecho aponta na direção da independência entre os vícios porque, como indicado, uma posse justa é a que não foi obtida por modo viciado; uma posse de boafé é aquela em que vícios ou obstáculos são ignorados.

A base de sustentação da tese de independência entre os vícios passa por essa diferenciação, que permitiria uma posse justa por ausência de vício, mas ilegítima, em função de um "obstáculo". Se a posse é justa e sem qualquer problema existente na sua aquisição, não teria sentido falar em 'boa-fé' ou 'má-fé', porque não haveria nada para ser ignorado ou conhecido.

Mas quais seriam as situações onde o possuidor legitimo perde a sua posse para outrem sem que tal aquisição esteja enquadrada nas modalidades de vício? Onde seria possivel enxergar um "obstáculo", como um modo de aquisição que torna a posse ilegítima, sem que o mesmo possa ser enquadrado como um "vício" objetivo, gerador de uma posse injusta?

O caso através do qual normalmente se costuma ilustrar a tese da independência, indicando uma situação onde haveria um "obstáculo", mas

${ }^{4}$ A citação se repete literalmente em TARTUCE; SIMÃO: 2010; p.63.

26 R. Fac. Dir. UFG, V. 37, n. 02, p. 13 - 40, jul. / dez. 2013 
não um "vício" na obtenção da posse é o da aquisição a non domino. Por esse motivo, para verificar a correção dessa interpretação esse modo de aquisição da posse deve ser minuciosamente analisado.

\subsection{Olhando a aquisição a non domino mais de perto}

Esse tipo de aquisição da posse se estrutura da seguinte forma: alguém esbulha a posse de outrem e a transmite para um terceiro. Este não obteve a posse de nenhuma dos modos elencados no artigo 1200 do Código Civil e, portanto, sua posse é justa. Se o terceiro obteve a posse do esbulhador através de um negócio jurídico, não há como enquadrar tal modo de aquisição entre as hipóteses de vícios: não houve violência, nem clandestinidade, tampouco precariedade 5 . Em uma palavra, o negócio jurídico realizado não se equipara a um vício.

Ao mesmo tempo, não é possivel deixar de reconhecer que o possuidor esbulhado tem melhor direito do que o terceiro que obteve a posse do esbulhador. Por isso, diz-se que o adquirente teria uma posse justa, mas ilegítima, em função do obstáculo decorrente do fato dela ter sido obtida de um possuidor injusto.

Diante de tais elementos, a posse do terceiro adquirente poderia ser encarada como um exemplo claro da existência de uma diferenciação entre os conceitos de vício ou obstáculo e, conseqüentemente, como uma defesa da independência entre os vícios objetivos e subjetivos. Se ele tiver conhecimento do vício da posse que está adquirindo, haverá posse justa e de má-fé, ao passo que, se ele ignora o vício de origem, sua posse será justa e de boa-fé.

Mas há outra maneira de enxergar as coisas. A aquisição da posse por parte do terceiro é uma das hipóteses de aquisição derivada de direitos. Conseqüentemente, a qualificação da posse do sucessor singular, o adquirente a non domino, depende de como se vislumbra a relação entre o

5 Este entendimento corrobora a tese do elenco numerus clausus de vícios, conforme defendido em: CHAVES; ROSENVALD: 2010; p.83 Não é essa, porém, a tese majoritária, como se pode ver em: LOUREIRO: 2008; p.1090; GONÇALVES: 2003; p.46. 
titular original de um direito e o seu sucessor, ou seja, sobre como se enxerga a dinâmica da aquisição derivada.

Duas posições se destacam aqui: aquela que entende que mesmo sendo a hipótese de aquisição derivada, não há uma relação de continuidade entre o direito de cada um dos envolvidos na transmissão; e a posição que considera o direito do adquirente como uma continuação daquele que era titularizado pelo possuidor injusto que o transmitiu.

A primeira posição pode ser ilustrada pelo pensamento de Carvalho Santos (1961; p.72), quando ele escreve que: “(..) a posse [do sucessor singular] começando na própria pessoa deste, não sendo a continuação da posse daquele a quem havia recebido a coisa, não pode participar dos vícios que esta possa ter." Ou seja, o adquirente a non domino - aquele que obteve a posse através de um negócio jurídico realizado com o possuidor injusto tem uma posse que não é uma continuação daquela de quem havia recebido a coisa. Se isso é assim, ele tem posse justa, ainda que a tenha obtido de um possuidor injusto.

O autor está implicitamente considerando que em uma aquisição derivada de direitos, o direito de quem recebe não é o mesmo de quem transmite, havendo uma solução de continuidade entre os dois. É que pode ser constatado na passagem em que Carvalho Santos indica que a posse do adquirente, "começando na própria pessoa deste", não é "a continuação da posse daquele a quem havia recebido a coisa".

Qual a conseqüência prática desse entendimento? Esse terceiro adquirente não poderia, por exemplo, ser colocado na posição de réu numa ação possessória e, como conseqüência, o esbulhado só poderia tentar retomar o seu direito através de uma ação reivindicatória, ou seja, no juízo petitório. Ao mesmo tempo, se o terceiro tem posse justa, poderia até mesmo usucapir na modalidade ordinária, de acordo com o entendimento prevalecente de que somente a posse justa é capaz de viabilizar essa espécie de usucapião.

Mas a estrutura da aquisição derivada pode ser vislumbrada pela segunda interpretação anteriormente indicada. Mesmo não sendo possível 
enquadrar a posse do sucessor singular entre as hipóteses de vício expressamente previstas pelo legislador, ela poderia ser considerada uma posse injusta simplesmente por ser uma continuação daquela que era exercida pelo transmissor, ou seja, o esbulhador. Não é injusta por se equiparar a uma das situações de vício legalmente previstas, mas por ser a continuação da posse viciada na origem.

Se a aquisição é derivada justamente porque tem origem em um 29 direito preexistente, o terceiro teria a mesma posse que o possuidor injusto tinha, ou seja, teria posse injusta, e ainda que o seu modo de aquisição não possa ser considerado em si mesmo como uma das hipóteses de vícios. Ao contrário do que vislumbrou Carvalho Santos, haveria sim uma continuação entre os direitos do transmissor e do terceiro adquirente.

É a esse entendimento que Orlando Gomes parece fazer referência na segunda parte do trecho anteriormente citado, onde se lê que: "Mas, $a$ transmissão dos vícios de aquisição permite que um possuidor de boa-fé tenha posse injusta, se a adquire de quem a obteve pela violência, pela clandestinidade ou precariedade, ignorante da ocorrência."6

Qual das duas posições é a mais correta? A posse do adquirente é ou não uma continuação da posse do esbulhador? A resposta é: sim, é.

Sendo a aquisição a non domino uma forma de aquisição derivada de direitos, inegavelmente é a continuidade do direito anterior, sem o quê sua posse seria originária, e não derivada. Ao mesmo tempo, a aquisição derivada de direitos está também submetida à tradicional regra presente na teoria geral do Direito Civil de que "ninguém pode transmitir mais direitos do que possui”.

Inegavelmente a posse injusta oferece oportunidades menores do que a posse justa. O possuidor injusto, por exemplo, está sujeito à análise de sua má-fé ou boa-fé, com reflexos na usucapião, na disciplina dos frutos,

6 No mesmo sentido, "A posse de quem adquire uma coisa, ignorando que o transmitente a assumira mediante violência, se qualifica como de boa-fé e injusta." NADER: 2008; p.48. 
etc. Como conseqüência, ter uma posse justa é ter menos direitos do que ter uma posse justa.

Em tais condições, até seria possivel dizer que o terceiro adquirente a non domino realmente não incorreu em nenhuma das hipóteses viciosas do artigo 1200. Mas nem por isso ele teria posse justa, eis que o seu direito é derivado do direito anterior e, novamente, como ninguém pode transmitir mais direitos do que tem, o possuidor injusto só pode transmitir uma posse injusta. Caio Mário da Silva Pereira (2010; p.397) explica a questão de forma direta:

"Se por aquisição originária, problema é apenas a
investigação do fato da aquisição, sem se cogitar da fase
anterior ao instante em que a relação jurídica surgiu
para o titular. Desde que assentada a justaposição do
sujeito ao direito, em virtude do fato aquisitivo hábil, e a
observância das prescrições legais, conclui-se pela sua
pureza. Se, ao revés, é derivada, será preciso cogitar se o
fenômeno da aquisição foi regular, e, também, da
integridade do direito preexistente, de vez que, se não
era escorreito no antecessor, vicioso passou ao atual
titular, pois ninguém pode transferir mais direitos do
que tem: 'nemo plus iuris ad alium transferre poteste
quam ipse habet."

Outro fator ainda pode ser ressaltado para reforçar o entendimento de que o possuidor injusto só pode transmitir uma posse injusta. $O$ pensamento de Carvalho Santos - exemplificativamente utilizado como fundamento da tese de que o terceiro adquirente pode ter uma posse justa derivada de uma posse injusta - está pautado pelo entendimento de que a posse do sucessor singular não é uma continuação daquela que era exercida pelo esbulhador. Mas esse modo de enxergar o problema fica ainda mais

7 Nesta linha de entendimento, foi aprovado na V Jornada de Direito Civil, promovida pelo Conselho da Justiça Federal/STJ, em novembro de 2011 em Brasília o seguinte enunciado, de autoria de Gustavo Tepedino, Marcus Dantas e Pablo Renteria: "A faculdade conferida ao sucessor singular de somar ou não o tempo da posse de seu antecessor não significa que, ao optar por nova contagem, estará livre do vício objetivo que maculava a posse anterior.”. Posicionando-se favoravelmente a este entendimento, ver: CHAVES; ROSENVALD: 2012; p.83. 
dificil de ser sustentado quando contraposto ao instituto da acessio possessionis, positivado pelo legislador no artigo 1207 do Código Civil8.

Tendo em vista a possibilidade de usucapir o bem - sem dúvida um dos principais efeitos da posse - a acessio permite que o terceiro realize uma soma do seu próprio período de exercício da posse com o período do seu antecessor. Inegavelmente o objetivo é conseguir obter de forma mais rápida o tempo necessário para usucapião (DINIZ: 2012; p.73). Trata-se de uma faculdade dada pelo legislador ao terceiro e que gera interpretações divergentes acerca da qualificação da sua posse.

Para uma parte da doutrina, ao decidir não realizar a soma dos períodos o sucessor teria uma posse absolutamente nova, na linha do entendimento de Carvalho Santos. A posse do sucessor estaria depurada dos vícios de origem, eis que não haveria uma continuidade entre elas. Por outro lado, há os que consideram que a existência dessa faculdade em nada modifica a estrutura comum da aquisição derivada analisada anteriormente, ou seja, o sucessor teria a mesma posse do seu antecessor.

Como qualificar a posse do terceiro, tendo em vista não somente a estrutura da aquisição derivada, mas também a faculdade de união dos tempos de posse criada pelo legislador?

\section{Aquisição a non domino e a acessio possessionis}

Se o argumento de Carvalho Santos para a defesa da justiça da posse do sucessor está fundado na idéia de que ele não é um continuador da posse do seu antecessor, a acessio acaba trazendo uma dificuldade adicional a este entendimento. Isso porque ao exercer a faculdade de unir os períodos de exercício de posse, a pretensa solução de continuidade desaparece e, portanto, o adquirente a non domino passa a ter uma posse com as mesmas características da que era exercida pelo esbulhador, ou seja, uma posse injusta.

8 "Art.1207: "O sucessor universal continua de direito a posse do seu antecessor; e ao sucessor singular é facultado unir sua posse à do antecessor, para os efeitos legais." 
Assim, se já é difícil não reconhecer que a dinâmica da aquisição derivada basta para mostrar que a posse do sucessor é a continuidade da posse do antecessor, parece então insustentável falar de uma solução de continuidade entre as posses quando a acessio é exercida.

Ao considerar que o adquirente tem posse justa, Carvalho Santos não leva em conta a sobredita regra acerca da aquisição derivada; ao considerar que a posse do terceiro não é uma continuação da que era exercida pelo esbulhador, deixa de lado o que ocorre na acessio.

Grande parte dos estudiosos, porém, vai além desse ponto, interpretando o artigo 1207 como uma forma do sucessor singular sanar os vícios existentes na posse. Se ela não contiver vícios, nenhum problema em somar os tempos de exercício. Mas se aquisição tiver sido viciosa em sua origem, seria mais conveniente ao adquirente começar outro período de exercício, totalmente desvinculado do anterior e, portanto, livre de vícios, o que não deixa de ser uma variação da tese de Carvalho Santos acerca da descontinuidade entre as posses. É o que se lê na obra de Carlos Roberto Gonçalves (2011; p.116):

"A acessio possessionis não é (...) obrigatória, mas facultativa. Se fizer uso da faculdade legal, sua posse permanecerá eivada dos mesmos vícios da anterior. Se preferir desligar sua posse da do antecessor, estará purgando-a dos vícios que a maculavam, iniciando, com a nova posse, prazo para usucapião."9

Tanto o entendimento de que há uma solução de continuidade entre as posses, quanto o de que os vícios são sanáveis pelo não exercício da acessio podem ser fortemente criticados pelos mesmos argumentos anteriores: ninguém pode transmitir mais direitos do que possui, de modo que o possuidor injusto não tem como transmitir uma posse justa em hipótese alguma.

9 Da mesma forma: "Se o autor da herança transmite ao herdeiro posse injusta, esta continuará necessariamente com o vício. $O$ sucessor singular tem a prerrogativa de escolher unir sua posse à do antecessor ou não. Esse aspecto ganha importância no usucapião." VENOSA: 2011; p.77. E ainda: "Como a união das posses, na sucessão singular, é facultativa, o novo possuidor, para o fim de ter posse isenta de vícios, própria para usucapir, pode deixar de unir, à sua, a posse anterior, por ser portadora de vícios." BESSONE: 1996; p.209. 
O legislador criou apenas a faculdade de realizar a soma, não a de apagar os defeitos eventualmente presentes na posse. Se não houvesse tal positivação, a faculdade também não existiria. Mas, se a posse originária é injusta, somando ou não o seu tempo de posse com o do antecessor, o terceiro tem posse injusta, em respeito à dinâmica da aquisição derivada de direitos. A mudança na qualificação da posse só existiria pela alteração da própria causa possessionis, como ocorreria através da usucapião, por exemplo.

Em tais condições, o exemplo padrão de uma posse "justa" e de "boa-fé" ou de "má-fé", aquele que normalmente embasa o argumento daqueles que defendem a tese da independência entre os vícios, pode ser fortemente criticado. A aquisição a non domino, como hipótese inegável de aquisição derivada, não faz com que uma posse originariamente injusta possa ser vista como uma posse justa, eis que não há solução de continuidade entre a transmitida e a recebida.

Ademais, se na aquisição derivada transmite-se a mesma posse que se titulariza, então a propalada diferenciação entre "vício" e "obstáculo" que compõe a tese da independência entre os vícios na verdade não existe, ao menos na situação modelo que se utiliza para demonstrá-la. A posse do terceiro adquirente a non domino é viciada da mesma forma que era a do seu antecessor.

Mas é preciso examinar ainda outras hipóteses utilizadas pelos defensores da tese da independência para justificar a possibilidade de uma posse "justa" e, ao mesmo tempo, de "boa-fé" ou de "má-fé", no intuito de verificar a correção do argumento em outros exemplos.

\section{Posse justa e ilegitima: para além da aquisição a non domino}

Parte da doutrina trabalha com outros exemplos de uma posse 'justa' eis que não foi adquirida mediante violência, clandestinidade nem precariedade, mas 'ilegítima', posto que repudie ao direito em função da existência de um 'obstáculo' que não se caracteriza como vício. 
Fábio Ulhôa Coelho (2011; p.38), por exemplo, constrói a seguinte situação:

“(..) se alguém encontrou na rua um envelope com dinheiro, cujo dono não é possivel identificar e, em vez de o levar à autoridade policial, resolve apropriar-se do bem exerce posse de má-fé (tem plena consciência de que aquele dinheiro não é dele), mas justa (mansa, pacífica e induvidosa)."

Sem dúvida que a hipótese não é de violência, nem de clandestinidade, tampouco precariedade. Mas será possivel considerar a posse daí decorrente como justa?

Não há como deixar de lado o fato de que a descoberta, em sua tipificação normativa, exige do descobridor a devolução da coisa à autoridade competente, conforme está consignado no artigo $1233 .{ }^{10}$ Conseqüentemente, o descumprimento de uma obrigação legalmente instituída enseja um ilícito de natureza civil. É razoável considerar a posse decorrente de um frontal descumprimento da legislação, um ilícito, portanto, seja uma posse justa?

A resposta certamente dependerá de como o intérprete lida com o fato do legislador ter se referido expressamente a somente três situações viciosas no artigo 1200 do Código Civil. Haveria ali um rol exaustivo ou exemplificativo?

A doutrina majoritariamente considera que o elenco estipulado pelo Código Civil é exemplificativo (LOUREIRO: 2008; p.1090); (GONÇALVES: 2003; p.46), deixando em aberto a possibilidade de identificação de outras situações de vício. ${ }^{11}$ Ademais ao se levar em consideração a tradição da própria doutrina civilística, ${ }^{12}$ de aproximar as três situações ali aventadas

10 "Art. 1.233. Quem quer que ache coisa alheia perdida há de restituí-la ao dono ou legitimo possuidor.

Parágrafo único. Não o conhecendo, o descobridor fará por encontrá-lo, e, se não o encontrar, entregará a coisa achada à autoridade competente."

11 Esse não é um entendimento livre de controvérsias. Parte da doutrina considera que a verificação do cumprimento da função social é fundamental para a caracterização de um possivel vício da posse. Nesse sentido: CHAVES; ROSENVALD: 2010; p.83; TARTUCE; SIMÃO: 2010; p.57.

12 Impossivel aqui deixar de fazer uma menção honrosa ao pensamento de San Tiago Dantas que, com a argúcia que lhe era peculiar, faz uma ressalva quanto à correspondência total entre as figuras viciosas do Código Civil e os tipos penais, 
com os ilícitos penais que seriam pretensamente respectivos, não haveria nenhuma razão essencial para deixar de lado outras hipóteses de ilicitude expressamente reconhecidas.

Uma terceira situação, talvez mais desafiadora, seja aquela na qual a violência é empregada para a realização de um negócio jurídico do qual advém a posse. É muito comum que se diga que seria em primeiro lugar necessário proceder à anulação do negócio de onde a posse decorre para só então torná-la injusta, eis que, como a posse é decorrente do negócio, não haveria vício em sua origem. Duas citações são importantes para a avaliação da correção desse entendimento. Em primeiro lugar, San Tiago Dantas (1979; p.61) considera que:

"Se, por exemplo, constrange-se alguém a formar com outrem um contrato de locação, e aquele que contratou metus causa, depois, espontaneamente e em obediência ao contrato, entre a coisa, essa posse não é violenta, por isso que não houve violência no ato do estabelecimento da posse. Houve violência no contrato, que se celebrou anteriormente e, por isso, a locação é anulável, sobre ela incidindo um vício de ato jurídico, mas a posse não é viciosa; é boa, é justa. O que se tem a fazer é anular o ato jurídico e, depois, recuperar a coisa, cuja posse é insubsistente, não tem causa."

Raciocínio semelhante é desenvolvido por Ebert Chamoun:

"Se a posse é derivada, funda-se num contrato. Existem, então, dois momentos na posse derivada: a) o momento em que o contrato é celebrado; b) o momento em que a coisa é transferida de uma pessoa para outra. Violenta diz-se a posse quando há violência no segundo momento. Se tem origem contratual a posse, violenta ela será não quando existe violência no momento do contrato, senão quando existe violência no momento do qual a posse provém, ou em que a posse se funda, ou seja, no momento em que a coisa materialmente se transfere. Exemplo: uma pessoa coagiu a outra a realizar um contrato de comodato, empregou violência material na redação do contrato. $\mathrm{O}$ ato jurídico é anulável. A coisa

mostrando que essa pretensa similitude "não quer dizer que haja, necessariamente, uma correspondência criminar para cada um dos vícios da posse". DANTAS: 1979; p.62. 
se não transferiu ainda, permanece em poder desse comodante coato. Eis todavia que o comodante, depois de ter sido coagido, reflete e verifica que tem razões para fazer o empréstimo. Perdoa o comodatário, não deseja anular o contrato. Pacificamente lhe entrega a coisa. Pergunta-se: é violenta essa posse? Não, porque a violência existiu no contrato, mas não existiu no ato originário, no ato do qual propriamente a posse provêm, estado de fato que ela é."13

As citações trazem informações muito relevantes para a compreensão do tema. Vê-se que os autores consideram que a violência só macula a posse se for o meio através do qual o possuidor a obtém diretamente. Eis o caso clássico do esbulho, quando o invasor utiliza a violência para retirar o ocupante do imóvel e se manter nele. Mas dois trechos parecem essenciais para a compreensão do modo como os doutrinadores constroem a sua interpretação.

San Tiago Dantas escreve que "Se, por exemplo, constrange-se alguém a formar com outrem um contrato de locação, e aquele que contratou metus causa, depois, espontaneamente e em obediência ao contrato, entrega a coisa, essa posse não é violenta”

Como alguém pode entregar espontaneamente o objeto do contrato se foi coagido a realizá-lo? Se há coação, não há espontaneidade. Quem realiza um contrato, o faz no intuito de alcançar o resultado prático decorrente dele, de modo que interpretar esses dois momentos como absolutamente estanques parece ser questionável e excessivamente formalista.

Fica ainda mais dificil de compreender quando se fala que o coagido 'espontaneamente' 'obedeceu' ao disposto no instrumento contratual. A coação, como se indicou, é elemento que retira a espontaneidade, e o mesmo pode-se dizer da obediência: quem obedece não é livre, ou seja, age motivado, no caso, coagido por outrem.

13 Ebert Chamoun, Faculdade de Direito da UEG. Conselho Universitário. Aulas do quarto ano datilografadas sem responsabilidade de cátedra, Rio de Janeiro, 1973. 
Na mesma linha de San Tiago Dantas, vê-se que a conexão entre os dois momentos - o da realização do negócio e o da obtenção material de seu resultado - é tão intensa que para estabelecer um ponto de separação entre eles Ebert Chamoun faz referência a um 'perdão' tácito realizado pelo coagido (!!) quando do cumprimento do objeto do contrato: "Eis todavia que o comodante, depois de ter sido coagido, reflete e verifica que tem razões para fazer o empréstimo. Perdoa o comodatário, não deseja anular o contrato. Pacificamente lhe entrega a coisa".

Imagine-se a situação: alguém posto sob a mira de uma arma é coagido a assinar um contrato através do qual se compromete a realizar um comodato e, moto contínuo entrega o bem objeto do negócio. Seria razoável entender que "uma coisa é o contrato" e "outra coisa é o momento de aquisição da posse"? É possivel dizer que e coisa foi entregue pacificamente? Ao que parece, não.

A situação precisa se explorada mais intensamente. Duas situações devem ser destacadas: a primeira, relativa ao momento em que a posse é entregue; a segunda, relativa a inserção de uma nova causa para a posse que se adquire.

Quando a violência é utilizada para a realização de um negócio jurídico que gera imediatamente a transferência da posse - como ocorreria quando do seu emprego para realização de um contrato de locação seguido da entrega das chaves do imóvel - não há como deixar de reconhecer que essa posse é injusta. A realização do contrato na hipótese é mero expediente formal através do qual a injustiça da posse pretende ser escamoteada.

Por outro lado, quando o negócio é celebrado e, passado um lapso indeterminado de tempo, mas suficiente para desfazer a relação de imediatismo, a vitima "perdoa" e entrega "espontaneamente" o objeto do negócio, há uma quebra entre os dois momentos, uma descontinuidade que aponta uma nova razão de ser da posse: a autorização aparece como fundamento da posse, agora justa, exercida pelo favorecido.

Nesse sentido é a observação de Silvio de Salvo Venosa (2011; p.69): 
"Quando alguém firma contrato de venda de um imóvel sob ameaças e em seguida entrega a posse, é elementar presumir que cumpre o pacto cedendo às mesmas ameaças que o obrigaram a firmá-lo. Por outro lado, pode ocorrer que a avença tenha sido firmada sob violência, mas a entrega da posse não, porque o outorgante se convenceu posteriormente da conveniência do negócio. Nessa hipótese, não haverá vício na posse."14

Muitas vezes os doutrinadores defendem o entendimento de que a posse obtida mediante a realização de um negócio jurídico realizado mediante violência seria justa porque ela decorre da avença, ou seja, não foi obtida diretamente. Vê-se, portanto, que esse entendimento pode ser contestado: a posse é justa porque o coato perdoa a injustiça presente na origem da posse. Isso significa que, sem essa autorização, pressuposta simplesmente pelo fato do possuidor não reclamar de volta a posse transmitida, a posse adquirida através da realização do negócio jurídico mediante violência ou ameaça seria injusta também.

Há que se reconhecer que o momento da realização do negócio e o da entrega da posse em geral estão intrinsecamente ligados e parece razoável qualificar como injusta a posse decorrente de um negócio realizado sob coação, ao menos da forma como indicado nos trechos destacados anteriormente.

Em todos os três exemplos investigados, nota-se um esforço intelectual para encontrar situações nas quais a posse seria justa, ainda que ilegítima. Cabe então outra indagação: qual a vantagem em se ter uma posse "justa" e de "boa-fé", "justa" e de "má-fé", na linha da tese da independência entre os vícios objetivos e subjetivos da posse? O que se pretende evitar ampliando as hipóteses de posse justa afinal?

Muitos efeitos negativos da posse injusta poderiam ser vislumbrados, mas aqui somente um deles será aprofundado: a relação entre

14 Segundo Carlos Roberto Gonçalves (2011; p.69): "Se a tradição pelo coato foi feita como símbolo de transmissão de propriedade, há necessidade de anulação do negócio jurídico de transferência do dominio, para que esta deixe de valer. Todavia, se a tradição foi feita unicamente como modo de transmitir a posse, sem representar um negócio jurídico de transferência de domínio, desde logo a posse 
a injustiça da posse e a usucapião. Isso porque os defensores da tese da descontinuidade entre a posse do esbulhador e a do terceiro adquirente entendem que ao decidir não exercer a acessio, o sucessor singular teria sanado os vícios de origem presentes na posse que recebeu. Essa interpretação foi francamente contestada sob o argumento de que, não deixando de ser uma aquisição derivada, exercendo ou não a soma entre os períodos o adquirente teria a mesma posse do antecessor, justa ou injusta.

Mas uma questão ainda pode ser mais bem visualizada: quando defendem essa tese da descontinuidade pela via do saneamento dos vícios, pretendem os autores fazer surgir uma posse justa em favor do terceiro adquirente a non domino. Uma das conseqüências desse arranjo seria qualificar a sua posse para usucapião, mesmo na modalidade ordinária.

Passa-se então a examinar como se estruturaria o exercício da faculdade de soma das posses e a usucapião ordinária. O objetivo é demonstrar que mesmo que fosse correta a tese da descontinuidade e, portanto, o adquirente tivesse posse justa, ele não teria condições de usucapir por tal modalidade.

\section{Relação entre acessio possessionis e usucapião ordinária}

Quando se trata da usucapião é comum considerar a expressão "contínua e incontestada" presente no artigo 124215 do Código Civil como sinônima de "mansa e pacífica" que, por sua vez, seria equivalente à posse justa, já que uma posse obtida pela violência não seria "mansa e pacífica" (SENISE: 2011; p.177); (MONTEIRO: 2011; p.40); (COELHO: 2011; p.35). Mas se existem controvérsias acerca da possibilidade de uma posse injusta conduzir à usucapião, ao exercer a sua faculdade de unir os tempos de posse, o adquirente a non domino estaria sanando os vícios de origem e,

transmitida será injusta, porque obtida por coação moral, podendo aquele que a perdeu fazer uso das ações possessórias."

15 "Art. 1.242. Adquire também a propriedade do imóvel aquele que, contínua e incontestadamente, com justo título e boa-fé, o possuir por dez anos.

Parágrafo único. Será de cinco anos o prazo previsto neste artigo se o imóvel houver sido adquirido, onerosamente, com base no registro constante do respectivo cartório, cancelada posteriormente, desde que os possuidores nele tiverem 
portanto, tendo a posse justa necessária para usucapir, inclusive na modalidade ordinária.

Mas escapa àqueles que interpretam a questão dessa maneira o fato de que o Código Civil exige que na usucapião ordinária a posse seja “contínua e incontestada" e, também, de "boa-fé”. Nessa circunstância, como é possivel dizer que ela é de boa-fé se o adquirente, para decidir não unir o seu tempo de posse ao do antecessor, o faz justamente por saber que ela apresenta um vício de origem? Se ele está "purgando os vícios de origem" ao constatar a existência deles e decidindo não exercer sua faculdade, inegavelmente tem conhecimento dos vícios, ou seja, é possuidor de má-fé.

Mesmo abraçando a tese da descontinuidade e considerando a posse do adquirente como posse justa, não há como negar que ela será de má-fé, pois o não exercício da acessio decorre do conhecimento acerca do vício ou obstáculo que macula a posse.

Essa estrutura impede a aquisição pela usucapião ordinária, o que torna esse trabalho hermenêutico absolutamente sem efeito para esse fim, ou seja, se o objetivo é evitar a injustiça da posse para qualificá-la à condução da usucapião ordinária, isso não será possível por essa linha de entendimento.

A idéia de que a transmissão da posse é capaz de sanar o vício anteriormente existente poderia dar a entender também que o sucessor não seria parte legítima para figurar no pólo passivo de uma ação possessória, eis que a transmissão não equivale ao esbulho e sua posse seria justa. Melhor: a possibilidade de sanar a injustiça da posse parece construída também com o objetivo de impedir que o adquirente seja réu na ação de reintegração.

Mas o Código Civil é mais uma vez claro nesse ponto: se o sucessor singular souber do vício de origem, ele se equipara a uma espécie de cúmplice do esbulhador, o que faz com ele também possa ser réu numa ação de reintegração de posse, porque o art.1212 indica expressamente: "o estabelecido a sua moradia, ou realizado investimentos de interesse social e 
possuidor pode intentar a ação de esbulho ou de indenização, contra o terceiro, que recebeu a coisa esbulhada sabendo que o era."

Assim, os dois efeitos estariam pretensamente neutralizados pelo entendimento de que a posse do adquirente a non domino é justa continuariam presentes, não pela justiça ou injustiça da posse, mas sim pela má-fé que inevitavelmente estaria constatada.

Diante de tais considerações, é possivel dizer que existe uma conexão incontornável entre os vícios da posse, pelo menos quando se leva em conta o modo pelo qual comumente se faz a defesa da independência, ou seja, através do exemplo da aquisição a non domino. Essa conexão pode ser reconhecida por dois motivos: a regra de que ninguém pode transmitir mais direitos do que possui, e pelo fato de que a acessio inegavelmente põe em questão a manutenção da boa-fé do adquirente, impossibilitando-o tanto para usucapião ordinária quanto para livrar-se do pólo passivo da ação de reintegração.

\section{Conclusão:}

Diante do exposto, é necessário realizar um esforço de sistematização das informações.

Em primeiro lugar, se a posse injusta é a tradicionalmente conceituada como aquela adquirida de modo vicioso; e se a boa-fé diz respeito ao desconhecimento acerca dos vícios e obstáculos eventualmente existentes, então não haveria como concordar com uma independência entre os vícios objetivos e subjetivos. Subjetivamente se ignora algo que objetivamente existe, no caso, o vício.

Apesar disso, é comum se deparar com a defesa da independência entre os dois âmbitos, o que se chamou aqui de tese da independência. Ela se baseia numa diferenciação entre os conceitos de "vício" - as hipóteses expressamente indicadas no artigo 1200 do Código Civil - e as de "obstáculo" - todas as demais situações não viciosas, mas ilegitimas, contrárias ao direito do possuidor justo.

econômico." 
Uma dos exemplos mais utilizados para indicar a existência de uma posse "justa", mas "ilegítima" é o da aquisição a non domino, o caso do terceiro que adquire a posse do esbulhador. Inegavelmente a transmissão da posse nesses termos é um exemplo de aquisição derivada.

Mas, ao contrário do que a primeira vista poderia parecer, um dos maiores nomes do Direito Civil brasileiro, Carvalho Santos, justifica o entendimento de que o terceiro tem posse justa pela via daquilo que se chamou aqui de "tese da descontinuidade": a posse recebida pelo sucessor não seria a continuação daquela titularizada pelo possuidor injusto. Assim, o adquirente teria posse justa mesmo que ela tenha sido obtida de um possuidor injusto.

Ocorre que, sendo um exemplo de aquisição derivada, a transmissão da posse nesse caso está também submetida à tradicional regra de que ninguém pode transmitir mais direitos do que possui. Isso mostra que, ao contrário do que entendeu Carvalho Santos, a posse do terceiro é sim a continuação da posse injusta do esbulhador, possuindo as mesmas características dela. Em tais condições, na verdade, o legislador não fez a indicada diferenciação entre "vício" e "obstáculo", mesmo no exemplo mais tradicionalmente utilizado para demonstrar o contrário

A defesa da independência entre os vícios feita com base nesse caso tem como um de seus objetivos a restrição das hipóteses de posse injusta, permitindo, por exemplo, que o terceiro adquirente tivesse posse apta a usucapião e não pudesse figurar no pólo passivo de uma ação possessória. Mas também foi demonstrado que mesmo que fosse possivel concordar com a tese da descontinuidade a usucapião ordinária não seria alcançável posto que o adquirente teria necessariamente que ter conhecimento dos vícios de origem para decidir não realizar a acessio, ou seja, seria possuidor de má-fé. E em sendo assim, também poderia ser réu numa ação de reintegração de posse, por expressa determinação legal.

Sistematicamente é mais correto considerar que só existem vícios subjetivos porque existem os objetivos, ou seja, há uma relação entre eles. Tanto na boa-fé quanto na má-fé a posse é viciada, seja porque foi adquirida 
por uma das formas do artigo 1200 do Código Civil, seja porque os vícios originários são transmitidos para o sucessor singular, em respeito à Teoria Geral.

Quando a posse é absolutamente livre de vícios ou quaisquer outros eventuais problemas em sua constituição, simplesmente não faz sentido falar em posse de boa-fé ou de má-fé, porque não haverá o quê ignorar ou conhecer. Não seria possivel falar, por exemplo, em uma posse 'justa' e, ao mesmo tempo, 'boa-fé' ou de 'má-fé'. Ao mesmo tempo, admitida a correlação entre vícios objetivos e subjetivos, mesmo a posse injusta poderá gerar a usucapião em sua modalidade ordinária, vez o legislador faz apenas menção ao vício subjetivo da boa-fé, o que pressupõe logicamente que a posse é viciada.

\section{Referências bibliográficas:}

BESSONE, Darcy. Direitos Reais. São Paulo: Saraiva, 1996;

BEVILÁQUA, Clóvis. Direito das Coisas. Rio de Janeiro: Ed. Rio, 1976;

CARVALHO SANTOS, J.M. de. Código Civil Brasileiro Interpretado, vol.VII. $7^{\text {a }}$ ed., Rio de Janeiro: Freitas Bastos, 1961;

CHAVES. Cristiano; ROSEnVALD, Nelson. Direitos Reais. Rio de Janeiro: Lúmen Júris, 2010;

CHAMOUN, Ebert. Faculdade de Direito da UEG. Conselho Universitário. Aulas do quarto ano datilografadas sem responsabilidade de cátedra. Rio de Janeiro, 1973;

COElHo, Fábio Ulhôa. Curso de Direito Civil - Direito das Coisas e Direito Autoral. São Paulo: Saraiva, 2010;

DANTAS, Francisco Clementino San Tiago. Programa de Direito Civil, vol III - Direitos Reais. Atualizado por Laerson Mauro. Rio de Janeiro: Ed. Rio, 1979;

DANTAS, Marcus; RENTERIA, Pablo; TEPEDINO, Gustavo. Enunciado 423 da V Jornada de Direito Civil - CJF/STJ, Brasília, 2011;

DINIZ, Maria Helena. Curso de Direito Civil Brasileiro, vol.4 - Direito das

Coisas. São Paulo: Saraiva, 2012; 
GOMES, Orlando. Direitos Reais. $20^{\mathrm{a}}$ ed. Atualizada por Luiz Edson Fachin. Rio de Janeiro: Forense, 2010;

GONÇALVES, Carlos Roberto. Direito Civil Brasileiro, vol.5 - Direito das Coisas. São Paulo: Saraiva, 2011;

GONÇALVES. Marcus Vinícius Rios. Dos Vícios da posse. São Paulo: J. de Oliveira, 2003;

LISBOA, Roberto Senise. Manual de Direito Civil, vol.4 - Direitos Reais e Direitos Intelectuais. São Paulo: Saraiva, 2011;

LOUREIRO, Francisco Eduardo. In: PELUSO, Cezar (Coord.). Código Civil Comentado: doutrina e jurisprudência. São Paulo: Manole, 2008;

MONTEIRO, Washington de Barros. Direito Civil, vol.3 - Direito das Coisas, São Paulo: Saraiva, 2011;

NADER, Paulo. Curso de Direito Civil, vol.4 - Direito das Coisas. Rio de Janeiro: Forense, 2008;

RIZZARDO, Arnaldo. Direito das Coisas. Rio de Janeiro: Forense, 2007;

RODRIGUES, Silvio. Direito Civil, vol.v - Direito das Coisas. São Paulo: Saraiva, 2009;

SILVA PEREIRA, Caio Mário da. Instituições de Direito Civil, vol.I Introdução ao Direito Civil e Teoria Geral de Direito Civil. Rio de Janeiro: Forense, 2010;

TARTUCE, Flávio; SIMÃO, José Fernando. Direito Civil, vol.4 - Direito das Coisas. São Paulo: Método, 2009;

TEPEDINO, Gustavo; BARBOSA, Heloisa Helena; MORAES, Maria Celina Bodin. Código Civil Interpretado conforme a Constituição da República. Rio de Janeiro: Renovar, 2011;

VENOSA, Silvio de Salvo. Direito Civil, vol.5 - Direitos Reais. São Paulo: Atlas, 2011;

Referências legislativas:

Lei 10406/2002 - Código Civil:

Art. 1200;

Art.1201;

Art. 1207;

Art.1212; 
Art.1233;

Art.1242;

Lei 5869/1973 - Código de Processo Civil:

Art.927; 